\title{
Accounting
}

homepage: www.GrowingScience.com/ac/ac.html

\section{Characteristics of banks as determinants of profit management for Islamic and conventional banks in ASEAN}

\section{Suripto $^{\mathrm{a}^{*}}$ and Supriyanto ${ }^{\mathrm{a}}$}

\begin{tabular}{l}
${ }^{a}$ Department of Business Administration, \\
\hline C H R O N I C L E \\
\hline Article history: \\
Received: January 1, 2021 \\
Received in revised format: \\
January 232021 \\
Accepted: February 15, 2021 \\
Available online: \\
February 15, 2021 \\
\hline Keywords: \\
Earnings management \\
Sharia bank \\
Multiple discriminant analysis
\end{tabular}

\section{Introduction}

A critical question in the current banking system is how management behaves in providing valid and reliable financial information. This behaviour is closely related to earnings management, which determines the income size. In the context of current banking systems, there is profit sharing and interest-based system, which is well-known for Sharia and conventional banking, respectively. This difference affects management behaviour in terms of earnings. Therefore, there is a need to conduct a study on earnings management in both Sharia and conventional banks, in order to address the problem faced in controlling income (Lobo, 2017). Earnings management is a unique and interesting topic which develops more accurate proxies in bank settings, because of its relatively homogeneous sample (Garsva, Skuodas, \& Rudzioniene, 2012). Some studies were conducted on this topic by Elnahass et al. (2018), Mozayani and Parvizi, (2016), Packer and Zhu, (2012), and Savitri et al. (2020). Meanwhile, Chan, Li and Lin (2019) found that Sharia banking status does not determine earnings management. Furthermore, Othman and Mersni (2014) examine the factors influencing Sharia and conventional banking policies in three countries, namely Indonesia, Malaysia, and Brunei Darussalam. They explained that Sharia banking policy examined by DLLP, capital, and earnings management is more reliable than that of conventional. However, in terms of NPLs, it is weaker instead. This finding indicated that the behaviour of sharia banking earnings management is different from conventional. The sharia banking is based on Profile and Loss Sharing (PLS), while conventional system regards interest. The principles of sharia banking operationally

* Corresponding author.

E-mail address: suriptob.1969@fisip.unila.ac.id (Suripto)

(C) 2021 by the authors; licensee Growing Science, Canada doi: $10.5267 /$ j.ac.2021.2.020

\begin{abstract}
A B S T R A C T
This study aims to analyze company characteristics as a determinant of conventional and Islamic bank earnings management in several ASEAN countries (Association of South East Asian Nations). The Multiple Discriminant Analysis was applied to determine the differences between Islamic and
Conventional Banks. This test was conducted based on Capital Adequacy Ratio, Income Before Tax and Interest, Non-Performing and Changing Loans, and Company's Size in the banks of Indonesia, Malaysia, and Brunei Darussalam from 2014 to 2018. The data obtained from 200 banking entities between Capital Adequacy Ratio, Earnings Before Tax, Loan Loss Provision, Non-Performing and Changing Loans, and Company's Size as determinants of earnings management between Islamic and conventional banks. Also, it was found that Company's Size was the dominant variable determining the management differences. Based on Discriminant Analysis, there were significant differences in showed the highest contribution in determining earnings management in Islamic banks. Overall, this study found that conventional banks dominated Islamic system in practicing earnings management.
\end{abstract}

(C) 2021 by the authors; licensee Growing Science, Canada 
apply mudarabah and musharakah techniques sourced from classical jurisprudence to avoid (usury) interest. Therefore, Prima Sakti and Mohamad (2018) in their empirical study, stated that real and different economic activities support business transactions in Sharia banking. Another difference in Sharia banking is examined from the types of financing products used, namely musharaka and mudarabah, which have high capital compared to its debt. Therefore, it chooses a pro-cyclical model, which attempts to emulate conventional banking instruments by developing non Profile and Loss Sharing (PLS) (Soedarmono, Pramono, \& Tarazi, 2017). Mohd Isa, Voon Choong, Yong Gun Fie, \& Abdul Rashid, (2018) explained that the deposit rate in Sharia is similar to conventional banking. The Sharia system avoids high-risk investments because it is conservative and more of profit management. (Farook, Hassan, \& Clinch, 2014). Therefore, Islamic banking tends to have a smaller risk than conventional in earnings management. Inconsistent because the sample sizes are not represented (Othman \& Mersni, 2014).

The research in Malaysia, Bangladesh, Indonesia, and Pakistan showed that Islamic banks perform less earnings management than the conventional system (Quttainah et al., 2013). Based on previous research, the importance of organizational religiosity in making decisions for Sharia-oriented companies produce accountable financial reports (Lassoued, Attia, \& Sassi, 2018). The risk management in banking is very important, as Islamic system always reserves for loan losses, income smoothing, and investment risk which are regulated in the profit-loss sharing system (Boulila Taktak, Ben Slama Zouari, \& Boudriga, 2010). The explanation of earnings management uses the agency theory, where banks managers receive rewards in line with the increase in the company's financial performance (Leventis et al., 2011). Therefore, the reason for selecting the object of this research is that Sharia and conventional banking in ASEAN countries were established and developed together. In the HT \& Rama (2018) empirical study, Indonesia, Malaysia, and Brunei Darussalam are part of the Southeast Asian countries that are ranked as the highest in managing Islamic banking. This is because they have the same characteristics, for example, the majority of the population in the country are Muslim. Therefore, the development of Sharia banking in these countries is quite rapid in contrast to previous research by Othman and Mersni, (2014), which examined 21 Islamic- and 18 interest-based banking systems for eight years with limited data from seven middle-east countries.

\section{Theoretical foundation}

\section{Earnings management}

Earnings management is the manipulation of reported income such that the profit and loss account does not represent the real economic conditions of banking activity. One of the practices of earnings management is the smoothing, which aims to reduce the composition of net income for each period. Managers increase loan loss provisions (LLP) when the condition of income before LLP has a high value, and decreases when the earning before LLP is low, to stabilize net income (Curcio \& Hasan, 2015). LLP is a cost item on the income reflecting an assessment for the management of possible expected losses due to unpaid loans. And keeping the records of LLP reduces net income. Furthermore, Managers use valuations in reporting transactions to change financial statements, making stakeholders unable to obtain information that should be about company performance (Ceccobelli \& Giosi, 2019). Sharia banks differ from conventionals because they use a profit-sharing system known as Profit Loss Sharing or PLS (Pramono, Rosieta, \& Soedarmono, 2017). The earning management is practiced in order to improve bank performance, shown in CAMEL approach (Capital, Assets, Management, Earning and Liquidity). This means that the amount of CAMEL which is proxied by the capital adequacy ratio (Capital Adequacy Ratio), Earning (Earning Before Tax and Provisions), and bad credit (Non Performing Loan) determine earnings management practices (Elnahass, Izzeldin, \& Abdelsalam, 2014). According to Boulila Taktak, Ben Slama Zouari, \& Boudriga, (2010), both conventional and Islamic banks carry out earnings management or LLP (Elnahass et al., 2014). However, no evidence of earnings management by Islamic system was found from this study to explain bank characteristics, which include CAR (Positive and Significant), Size (Negative and Significant), and Loans (Positive and Significant).

\section{Model development}

The business model of PLS in sharia banks limits the ability to manage earnings through LLP. Also, the agency cost factor is relatively higher because investors are not engaged in business decisions directly, nor do they have board of directors' representatives. These reasons require investors to monitor investment through the publication of financial statements. In protecting their investments, they attempt to convince bank regulators to evaluate and develop the governance mechanisms in the sharia bank. This behaviour aims to enhance the quality of financial statements (Elnahass et al., 2018). One of the agency theory implications is that managers improve firm performance, and achieve rewards by applying LLP in income smoothing (Elnahass et al., 2018). The use of reserves in Sharia and conventional banks is very different. The reserve policy on sharia banks is better than conventionals in that it considers not only actual, and also future losses (Othman \& Mersni, 2014). Earnings management is measured using two concepts, discretionary and non-discretionary accruals. The discretionary accrual is the recognition of profit or expense, which is a management choice. In contrast, non-discretionary accruals are the recognition of reasonable profit which affect the financial statements (Faradila \& Cahyati, 2013). Several factors influence earnings management using LLP, such as Capital Adequacy Ratio (CAR), Earnings before Tax, and Loan Loss Provisions (EBTLLP), 
Non-Performing Loans (NPL), Change Loans (CLOANS), and Size. CAR is defined as bank capital expressed as a percentage of the weighted risk. The minimum ratio guarantees banks to absorb the losses before experiencing financial difficulties (Mili, Sahut, Trimeche, \& Teulon, 2017). A high allowance when capital is low is consistent with a reduced capital acquisition cost that correlates with more exceptional LLP practices (Packer \& Zhu, 2012). Furthermore, EBTLLP is a measure of the bankability to use assets in generating income before tax and LLP (Elnahass et al., 2018). Assets of good quality increase higher profitability. Therefore, it is imperative for banks to efficiently manage asset quality and other factors of profitability (Swamy, 2017). Meanwhile, Non-Performing Loans (NPL) is the ratio of impaired to the total loans. Change Loans (CLOANS) transforms in the total loans from the current and the previous year (Elnahass et al., 2018). Variable NPL and CLOANS are used to measure the credit quality because it is more of a risk than other types of assets (cash, reserves, bonds), therefore, high loans are associated with low credit quality (Packer \& Zhu, 2012). Size is related to the company's internal control system which reduces the suspicion of earnings management. Large companies have more effective internal control systems and competent auditor teams than the smallest. This leads to the reliability of the public financial statements (Ali, Noor, Khurshid, \& Mahmood, 2015). Abdelsalam et al., (2016) and Lassoued et al., (2018) examined the banks in middle-east and north Africa countries, in which conventional-based manage earnings more than the sharia. This is because sharia banks tend to manage income by reporting earnings and discretionary accrual cases. The study of Caporale et al., (2018) showed that earnings management in Italian banks is counter-cyclical with non-discretionary components, while macroeconomic shocks play an important role. CKPN has less occurrence in the case of local banks, because their loans are more guaranteed, and supervisory activities strongly influence their behaviour. The study of Shawtari et al., (2019) conducted in Indonesia, stated that earnings management at sharia-based banks is lower than conventionals, which is similar to the results of Othman \& Mersni, (2014) study. Pinto \& Ng Picoto, (2018) explained that managers use LLP to manage income and capital regulation. The key provisions of LLP are size and NPL, while Elnahass et al., (2018) showed the practice of earnings management through CKPN in conventional-based, especially in large banks that suffered losses. Conversely, sharia system tend not to use CKPN in earnings or capital management. The difference is due to the limited sharia banking business model, strict governance, and ethical orientation.

\section{Theoretical foundation}

\section{Earnings management}

Earnings management is the manipulation of reported income such that the profit and loss account does not represent the real economic conditions of banking activity. One of the practices of earnings management is the smoothing, which aims to reduce the composition of net income for each period. Managers increase loan loss provisions (LLP) when the condition of income before LLP has a high value, and decreases when the earning before LLP is low, to stabilize net income (Curcio \& Hasan, 2015). LLP is a cost item on the income reflecting an assessment for the management of possible expected losses due to unpaid loans. And keeping the records of LLP reduces net income. Furthermore, Managers use valuations in reporting transactions to change financial statements, making stakeholders unable to obtain information that should be about company performance (Ceccobelli $\&$ Giosi, 2019). Sharia banks differ from conventionals because they use a profit-sharing system known as Profit Loss Sharing or PLS (Pramono, Rosieta, \& Soedarmono, 2017). The earning management is practiced in order to improve bank performance, shown in CAMEL approach (Capital, Assets, Management, Earning and Liquidity). This means that the amount of CAMEL which is proxied by the capital adequacy ratio (Capital Adequacy Ratio), Earning (Earning Before Tax and Provisions), and bad credit (Non Performing Loan) determine earnings management practices (Elnahass, Izzeldin, \& Abdelsalam, 2014). According to Boulila Taktak, Ben Slama Zouari, \& Boudriga, (2010), both conventional and Islamic banks carry out earnings management or LLP (Elnahass et al., 2014). However, no evidence of earnings management by Islamic system was found from this study to explain bank characteristics, which include CAR (Positive and Significant), Size (Negative and Significant), and Loans (Positive and Significant).

\section{Model development}

The business model of PLS in sharia banks limits the ability to manage earnings through LLP. Also, the agency cost factor is relatively higher because investors are not engaged in business decisions directly, nor do they have board of directors' representatives. These reasons require investors to monitor investment through the publication of financial statements. In protecting their investments, they attempt to convince bank regulators to evaluate and develop the governance mechanisms in the sharia bank. This behaviour aims to enhance the quality of financial statements (Elnahass et al., 2018). One of the agency theory implications is that managers improve firm performance, and achieve rewards by applying LLP in income smoothing (Elnahass et al., 2018). The use of reserves in Sharia and conventional banks is very different. The reserve policy on sharia banks is better than conventionals in that it considers not only actual, and also future losses (Othman \& Mersni, 2014). Earnings management is measured using two concepts, discretionary and non-discretionary accruals. The discretionary accrual is the recognition of profit or expense, which is a management choice. In contrast, non-discretionary accruals are the recognition of reasonable profit which affect the financial statements (Faradila \& Cahyati, 2013). Several factors influence earnings management using LLP, such as Capital Adequacy Ratio (CAR), Earnings before Tax, and Loan Loss Provisions (EBTLLP), Non-Performing Loans (NPL), Change Loans (CLOANS), and Size. CAR is defined as bank capital expressed as a percentage 
of the weighted risk. The minimum ratio guarantees banks to absorb the losses before experiencing financial difficulties (Mili, Sahut, Trimeche, \& Teulon, 2017). A high allowance when capital is low is consistent with a reduced capital acquisition cost that correlates with more exceptional LLP practices (Packer \& Zhu, 2012). Furthermore, EBTLLP is a measure of the bankability to use assets in generating income before tax and LLP (Cevik \& Charap, 2015; Elnahass et al., 2018). Assets of good quality increase higher profitability. Therefore, it is imperative for banks to efficiently manage asset quality and other factors of profitability (Swamy, 2017). Meanwhile, Non-Performing Loans (NPL) is the ratio of impaired to the total loans. Change Loans (CLOANS) transforms in the total loans from the current and the previous year (Elnahass et al., 2018). Variable NPL and CLOANS are used to measure the credit quality because it is more of a risk than other types of assets (cash, reserves, bonds), therefore, high loans are associated with low credit quality (Beck et al., 2010; Packer \& Zhu, 2012). Size is related to the company's internal control system which reduces the suspicion of earnings management. Large companies have more effective internal control systems and competent auditor teams than the smallest. This leads to the reliability of the public financial statements (Ali, Noor, Khurshid, \& Mahmood, 2015). Abdelsalam et al., (2016) and Lassoued et al., (2018) examined the banks in middle-east and north Africa countries, in which conventional-based manage earnings more than the sharia. This is because sharia banks tend to manage income by reporting earnings and discretionary accrual cases. The study of Caporale et al., (2018) showed that earnings management in Italian banks is counter-cyclical with non-discretionary components, while macroeconomic shocks play an important role. CKPN has less occurrence in the case of local banks, because their loans are more guaranteed, and supervisory activities strongly influence their behaviour (Rafay et al., 2020). The study of Shawtari et al., (2019) conducted in Indonesia, stated that earnings management at sharia-based banks is lower than conventionals, which is similar to the results of Othman \& Mersni, (2014) study. Pinto \& Ng Picoto, (2018) explained that managers use LLP to manage income and capital regulation. The key provisions of LLP are size and NPL, while Elnahass et al., (2018) showed the practice of earnings management through CKPN in conventional-based, especially in large banks that suffered losses. Conversely, sharia system tend not to use CKPN in earnings or capital management. The difference is due to the limited sharia banking business model, strict governance, and ethical orientation.

\section{Methodology}

The data used in this study was obtained from the annual reports of Indonesia, Malaysia, and Brunei Darussalam Bank. The number of samples was 40 banks, consisting of 20 from conventional and 20 from sharia system, from 2014 to 2018 . This study compares the variables of conventional and Sharia banking in Indonesia, Malaysia, and Brunei Darussalam, which included CAR for capital measurement, EBTLLP for assessing credit risks, and company's size for evaluating the firm magnitude either classified as large, medium, or small.

\section{Capital Adequacy Ratio (CAR)}

CAR is the assessment of the modern banking system's safety. Banks are required to plan a certain amount from the capital to support the growth of productive assets that are in line with their working plan (Alhadab \& Al-Own, 2019). This ratio identifies bankability in providing reserve funds to minimize loss risks.

\section{Earnings Before Tax and Loan Loss Provisions (EBTLLP)}

EBTLLP is the capacity measurement in using its assets in generating earnings before its liabilities and CKPN (Elnahass et al., 2018). This ratio is measured as the banks' earnings before the reserve's impairment loss on total bank assets.

\section{Non-Performing Loans (NPL)}

NPL is the measurement of impaired credits, which is the main reason for default in banks. The high NPL should be balanced with the increased reserve fund (Fund, 2020). It is also defined as the inability of customers to pay part or all of their obligations to the bank.

\section{Change Loans (CLOANS)}

Change loans are the changes in the current year's credit value with the previous (Alhadab \& Al-Own, 2019).

Size

The company's size is an embodiment of the total owned assets, which includes the capital, rights, and obligations (Kartikasari \& Merianti, 2016; Jin, 2013; Mamipour \& Sepahi, 2015; Wijayanti et al., 2020). The firm or business size was based on several elements, one of which is the total assets. 
Multiple discriminant analysis have two main steps, the first step is the F-Test (Wilks Lambda) used to determine whether this model as a whole is significant or not. Second, assuming the F-Test shows significant value, then each independent variable is assessed for their differences. In the average group, this is used to classify the dependent variable. The discriminant equation is formulated as follows:

where

$\mathrm{L} \quad=$ linear combination of discriminating (independent) variable

$\mathrm{b} 1-\mathrm{bn}=$ discriminant coefficient

$\mathrm{c} \quad=$ constant value

$\mathrm{X}_{1} \quad=$ capital adequacy ratio (CAR)

$\mathrm{X}_{2} \quad=$ earning before tax and loan loss provisions (EBTLLP)

$\mathrm{X}_{3}=$ non-performing loans (NPL)

$\mathrm{X}_{4}=$ change loans

$\mathrm{X}_{5}=$ size

The Determinant of Cut-Off Value

Both groups observed in this study have several samples, therefore, the equation applied determines the cut-off point is as follows.

where

$\mathrm{ZCU}=$ critical point, as a function of cut-off score

$\mathrm{ZA}$ and $\mathrm{ZB}=$ centroid number for group 1 and 2

$\mathrm{NA}$ and $\mathrm{NB}=$ number of group 1 and 2

The cut-off determination is based on the average value of the total Z-score from each bank, which is 0.0000 . The standard applied to measure whether banks are classified as conventional or Sharia is as follows,

- When Z-score statistic $<0.000$, the bank is classified as a sharia.

- When Z-score statistic $>0.000$, the bank is classified as conventional.

\section{Results}

The descriptive analysis of Sharia and conventional banking was presented in Table 1 with the following variables, Capital Adequacy Ratio (CAR), Earning before Tax and Loan Loss Provisions (EBTLLP), Nonperforming Loans (NPL), and Company's Size. First, the statistical range of $15.69 \%$ in the conventional and $151.92 \%$ in the sharia banking showed a significant difference in CAR. Similarly, the statistical range values differed significantly in EBTLLP, which was $4.51 \%$ in conventional and $13.45 \%$ in sharia banking. Furthermore, the statistical range of conventional $(13.05 \%)$ and sharia banking $(61.20 \%)$ also showed significant differences in CLOANS. An insignificant comparison between Sharia and conventional banking occurred in the NPL and firm size variables with a statistical comparison of $9.06 \%: 4.95 \%$ for NPL, and $6.29 \%: 5.82 \%$ for Company's Size, respectively. Based on these values, there were significant differences between Sharia and conventional banking in the five determinants of earnings management. This showed that sharia banking did not follow the business model of conventional systems in earnings management practices. Second, a discriminant analysis was conducted by identifying which variables were significant in distinguishing earnings management between Sharia and conventional banking. From the equality test, the variable values, namely CAR, EBTLLP, CLOANS, and Size were below 0.05 . These test results showed that there were differences between the groups or determining variables. However, the NPL variable had significant value above 0.05 , which means there was no difference between the groups, or the value of the two groups is relatively the same. Third, the MDA model was used to determine the discriminant equation of the selected variables. The MDA model in the discriminant equation started with the variable that had the most significant $F$ value. In the first stage, the calculated F Size value was 0.573 . Then the NPL variable had a calculated $\mathrm{F}$ value of 0.471 , CLOANS was 0.461 , and EBTLLP was 0.451 . Finally, determining the cut-off value was based on the average value of the Z-Score. For the Multiple Discriminant Analysis (MDA) model, the Z-Score of each bank was 0,000 . When the Z-Score was $<0.000$, it was categorized as sharia, and when the Z-Score was $>0.000$, it was classed as a conventional-based system. 
Table 1

Statistical Descriptive

\begin{tabular}{ccccccc}
\hline \multirow{2}{*}{ Variable } & $\mathrm{N}$ & Min & Max & & Mean & \multicolumn{2}{c}{ Std. Deviation } \\
\cline { 2 - 7 } & Statistic & Statistic & Statistic & Statistic & Std. Error & Statistic \\
\hline \multirow{2}{*}{ CAR } & 100 & $10.52 \%$ & $26.21 \%$ & $18.0035 \%$ & $0.32691 \%$ & $3.26912 \%$ \\
& 100 & $11.15 \%$ & $163.07 \%$ & $21.6335 \%$ & $1.71102 \%$ & $17.11025 \%$ \\
\hline \multirow{2}{*}{ EBTLLP } & 100 & $0.30 \%$ & $4.81 \%$ & $2.4570 \%$ & $0.12965 \%$ & $1.29651 \%$ \\
& 100 & $-0.36 \%$ & $13.08 \%$ & $1.9395 \%$ & $0.20215 \%$ & $2.02150 \%$ \\
\hline \multirow{2}{*}{ NPL } & 100 & $0.40 \%$ & $9.46 \%$ & $2.4524 \%$ & $0.18672 \%$ & $1.86721 \%$ \\
& 100 & $0.02 \%$ & $4.97 \%$ & $2.0470 \%$ & $0.15384 \%$ & $1.53839 \%$ \\
\hline \multirow{2}{*}{ CLOANS } & 100 & $0.23 \%$ & $13.28 \%$ & $4.6773 \%$ & $0.28338 \%$ & $2.83384 \%$ \\
& 100 & $0.05 \%$ & $61.26 \%$ & $9.2239 \%$ & $0.84000 \%$ & $8.39995 \%$ \\
\hline \multirow{2}{*}{ SIZE } & 100 & 7.7757 & 14.075 & 11.85359 & .137108 & 1.3710764 \\
& 100 & 6.4953 & 12.325 & 9.598000 & .125316 & 1.2531569 \\
\hline
\end{tabular}

Source: the authors' calculations in Multiple Discriminant Analysis according to the statistical data

\subsection{Normality Test}

Table 2

One-Sample Kolmogorov-Smirnov Test

\begin{tabular}{|c|c|c|}
\hline \multirow{2}{*}{\multicolumn{2}{|c|}{$\mathrm{N}$}} & Unstandardized Residual \\
\hline & & 200 \\
\hline \multirow{2}{*}{ Normal Parameters } & Mean & .0000000 \\
\hline & Std. Deviation & .33616765 \\
\hline \multirow{3}{*}{ Most Extreme Differences } & Absolute & .056 \\
\hline & Positive & .055 \\
\hline & Negative & -.056 \\
\hline \multicolumn{2}{|c|}{ Test Statistic } & .056 \\
\hline \multicolumn{2}{|c|}{ Asymp. Sig. (2-tailed) } & .200 \\
\hline
\end{tabular}

Source: the authors' calculations in Multiple Discriminant Analysis according to the statistical data.

The data shown in Table 2 was from the Kolmogorov-Smirnov normality test. The table showed that all independent variables had a significant value of 0.200 , which was more than 0.05 . Which means that the independent variable was distributed to meet the assumptions that were used for discriminant analysis.

Table 3

Box's M Test

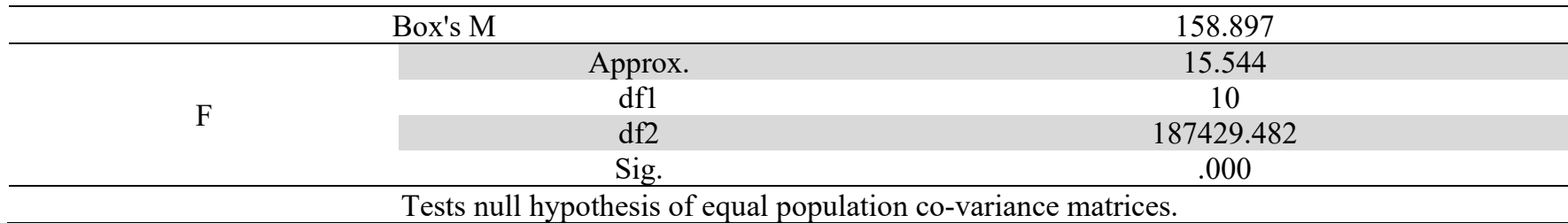

Source: the authors' calculations in Multiple Discriminant Analysis according to the statistical data.

The box's M test showed that the F value was 15.544 , and the significance was 0.000 . This caused the covariance matrix between the groups to violate the discriminant assumption, because the significance value was below 0.05 . However, the analysis of discriminant functions remained strong even though the assumption of variance homogeneity did not correlate.

\section{Table 4}

Discriminant Analysis

\begin{tabular}{|c|c|c|c|c|c|}
\hline & Wilks' Lambda & $\mathrm{F}$ & df1 & df2 & Sig. \\
\hline CAR & .979 & 4.342 & 1 & 198 & .038 \\
\hline EBTLLP & .977 & 4.644 & 1 & 198 & .032 \\
\hline NPL & .986 & 2.809 & 1 & 198 & .095 \\
\hline CLOANS & .883 & 26.303 & 1 & 198 & .000 \\
\hline SIZE & .573 & 147.458 & 1 & 198 & .000 \\
\hline
\end{tabular}

Source: the authors' calculations in Multiple Discriminant Analysis according to statistical data. 
From Table 4, the function of group centroid provided the information about average discriminant score. The discriminant score for conventional banks was 1.098, and -1.098 for Sharia, therefore, there was a stipulated cut-off value. Then the cut-off point of the discriminant function was calculated as follows:

Information :

ZCU $\quad=$ cut-off score

$\mathrm{ZA}$ and $\mathrm{ZB} \quad=$ centroid values for group 1 and 2

$\mathrm{NA}$ dan NB = number of group 1 and 2

From the MDA model, the cut-off determination was based on the average value of the Z-Score from each bank (0.000). The standards used to assess whether the bank was categorized as a sharia or conventional bank were:

- When Z-Score was calculated as $<0.000$, the bank was classified as a sharia.

-When Z-Score was $>0.000$, the bank was classed as a conventional.

\section{Table 5}

The determination of cut-off value

$\begin{array}{cc} & \text { Functions at Group Centroids } \\ \text { Bank System } & \text { Function } \\ & 1 \\ \text { Conventional Bank } & 1.098 \\ \text { Sharia Bank } & -1.098\end{array}$

Unstandardized canonical discriminant functions evaluated at group means

Source: the authors' calculations in Multiple Discriminant Analysis according to statistical data.

\section{Wilk's Lambda Test}

Based on the Wilk's Lambda test in Table 6, the Size, NPL, CLOANS, and EBTLLP had a significance value of 0.000 less than 0.05. Therefore, all independent variables included in the MDA model had a significant effect. Therefore, Size, NPL, CLOANS, and EBTLLP significantly affected earnings management in Sharia and conventional banking. Canonical correlation was used to measure the closeness of the relationship between the discriminant scores. In this study, there were two groups.

\section{Table 6}

Wilk's Lambda

\begin{tabular}{|c|c|c|c|c|c|c|c|c|}
\hline \multirow{2}{*}{$\begin{array}{l}\text { Number of } \\
\text { Variables }\end{array}$} & \multirow{2}{*}{ Lambda } & \multirow{2}{*}{ df1 } & \multirow{2}{*}{$\mathrm{df} 2$} & \multirow{2}{*}{ df3 } & \multicolumn{4}{|c|}{ Exact F } \\
\hline & & & & & Statistic & df1 & $\mathrm{df} 2$ & Sig. \\
\hline 1 & .573 & 1 & 1 & 198 & 147.458 & 1 & 198.000 & .000 \\
\hline 2 & .471 & 2 & 1 & 198 & 110.702 & 2 & 197.000 & .000 \\
\hline 3 & .461 & 3 & 1 & 198 & 76.465 & 3 & 196.000 & .000 \\
\hline 4 & .451 & 4 & 1 & 198 & 59.346 & 4 & 195.000 & .000 \\
\hline \multicolumn{2}{|c|}{$\begin{array}{c}\text { Eigenvalue } \\
1.217^{\mathrm{a}}\end{array}$} & \multicolumn{3}{|c|}{$\begin{array}{c}\% \text { of Variance } \\
100.0\end{array}$} & $\begin{array}{c}\text { Cumulative } \% \\
100.0\end{array}$ & \multicolumn{3}{|c|}{$\begin{array}{c}\text { Canonical Correlation } \\
.741 \\
\end{array}$} \\
\hline
\end{tabular}

Source: the authors' calculations in Multiple Discriminant Analysis according to statistical data.

The results in Table 6 noted the CR value of 0.741 . When squared $(0.741) 2=0.549$, it was found that $54.9 \%$ of variables explained the variation. Therefore, it was stated that the difference between Sharia and conventional banking groups was explained by the EBTLLP, NPL, CLOAN, and Size variables. The equation of Discriminant Analysis Functions unstandardized those formed from the results of the analysis as follows:

$Z=(-9.419)+0.117 E B T L L P+0.327 N P L+(-0.038) C L O A N S+0.810$ SIZE

\section{Accuracy of Classification Prediction}

Based on the table below, the accuracy of the prediction was $89 \%$. The accuracy of conventional banking was $91 \%$, and $87 \%$ for the sharia system. Misclassification in the conventional banking was $9 \%$ and $13 \%$ for the sharia system. This was because the value of earnings management, which was initially classified as conventional banking and after being calculated turns out to be in the category of sharia system, and vice versa.

Based on the results shown In Table 7, the EBTLLP, NPL, CLOANS, and Size variables were used to determine earnings management in sharia and conventional banking. The EBTLLP, CLOANS, and Size variables had a higher value compared to sharia banking, making this variable to be used as a determinant in conventional banking earnings management. The CLOANS 
variable in Sharia banking was more significant than the conventional system. In the discriminant model, the CAR variable did not enter the model because it did not meet the requirements.

Table 7

Classification results

\begin{tabular}{|c|c|c|c|c|c|}
\hline & & \multirow{2}{*}{ Banking System } & \multicolumn{2}{|c|}{ Predicted Group Membership } & \multirow{2}{*}{ Total } \\
\hline & & & Conventional & Sharia & \\
\hline \multirow{4}{*}{ Original } & \multirow{2}{*}{ Count } & Conventional & 91 & 9 & 100 \\
\hline & & Sharia & 13 & 87 & 100 \\
\hline & \multirow{2}{*}{$\%$} & Conventional & 91.0 & 9.0 & 100.0 \\
\hline & & Sharia & 13.0 & 87.0 & 100.0 \\
\hline \multirow{4}{*}{ Cross-validated $^{\mathrm{b}}$} & \multirow{2}{*}{ Count } & Conventional & 89 & 11 & 100 \\
\hline & & Sharia & 13 & 87 & 100 \\
\hline & \multirow{2}{*}{$\%$} & Conventional & 89.0 & 11.0 & 100.0 \\
\hline & & Sharia & 13.0 & 87.0 & 100.0 \\
\hline
\end{tabular}

\section{Discussion}

The results indicated that the average value of CARs in sharia was higher than conventional banking. This was in line with the research of Othman \& Mersni, (2014) which stated that CAR was significantly higher in sharia than conventional banking. The CAR variable had a positive relationship with earnings management. Therefore, the higher the CAR value, the greater the manager performs earnings management, and vice versa. However, this variable was not included in the function equation, because it did not meet the requirements. The findings showed that the average the value of EBTLLP had a significant difference between Sharia and conventional banking. The average value of EBTLLP in conventional was higher than sharia banking. This was in line with the research of Lassoued et al. (2018), which stated that sharia banking managed less income compared to conventional system. Dyreng et al. (2012), Dou et al., (2018), Ceccobelli and Giosi, (2019), and Bouvatier et al., (2014) showed significant results between EBTLLP and CKPN. In sharia banking, managers were not allowed to manipulate earnings, because it mislead users of financial statements. EBTLLP had a positive relationship with earnings management. The higher the profit generated, the greater the manager performs earnings management, and vice versa. Based on the results, there was no significant difference between the NPLs in Sharia and conventional banking. Based on the descriptive analysis, the average value of NPL in conventional banking was higher than sharia system. This was in line with the research of Elnahass et al., (2018) and Othman \& Mersni, (2014) stating that NPL have less significance in sharia banking. This variable has a positive relationship with earnings management. The higher the NPL value, the greater the manager preforms earnings management, and vice versa. Based on the results, there was significant difference between the CLOANS in Sharia and conventional banking. Based on the descriptive analysis, the average value of CLOANS in sharia banking was higher than conventional system. This was in line with the research of Elnahass et al., (2018) srating that changes in loans were less significant in sharia banking. This was also strengthened by Quttainah et al., (2013), stating that CLOANS was significant for CKPN. This variable had a positive relationship with earnings management. The greater the value of CLOANS, the higher earnings management, and vice versa. Based on the results, the Company's Size had a significant difference between both banking system. The descriptive analysis indicated that the average value of conventional banking Size was greater than that of the Sharia system. This was in line with the study of Elnahass et al., (2018), stating that earnings management was commonly used in conventional banking in large companies. Lassoued et al., (2018), Mollah and Zaman (2015) and Ceccobelli \& Giosi, (2019) showed significant positive results it. The research of Ahmed, Mohammed, \& Adisa (2014) showed that Sharia banking practice low management. Therefore, Size variable had a negative relationship with earnings management. The larger the Size of the company, the lower the profit management, and vice versa.

\section{Conclusion}

The data obtained from 200 banking entities were analyzed discriminately, and the findings showed that EBTLLP, NPL, CLOANS, and Size were different variables that determined the earnings management between conventional and Sharia banks. It was found that the EBTLLP, CLOANS, and Size showed significant differences, while the NPL did not. From the discriminant equation, the average ratio that was most dominant in predicting earnings management differences between the banking groups was the Size variable. The EBTLLP, NPL, and Size were mostly used in the determination of earnings management in conventional banks, while CLOANS was utilized in Sharia system. Overall, this study found that conventional banks dominanted the sharia system in practicing earnings management.

\section{References}

Abdelsalam, O., Dimitropoulos, P., Elnahass, M., \& Leventis, S. (2016). Earnings Management Behaviors Under Different Monitoring Mechanisms: The Case of Islamic and Conventional Banks. Journal of Economic Behavior and Organization, 132, 155- 173. https://doi.org/10.1016/j.jebo.2016.04.022. 
Ahmed, A., Mohammed, A. Y., \& Adisa, A. O. (2014). Loan Loss Provision and Earnings Management in Nigerian Deposit Money Banks. Mediterranean Journal of Social Sciences, 5(17), 49-58. https://doi.org/10.5901/mjss.2014.v5n17p49.

Alhadab, M., \& Al-Own, B. (2019). Earnings Management And Equity Incentives: Evidence from the European Banking Industry. International Journal of Accounting and Information Management, 27(2), 244-261. https://doi.org/10.1108/IJAIM-08-2017-0094.

Ali, U., Noor, M., Khurshid, M. K., \& Mahmood, A. (2015). Impact of Firm Size on Earnings Management: A Study of Textile Sector of Pakistan. SSRN Electronic Journal, 7(28), 47-56. https://doi.org/10.2139/ssrn.2698317.

Beck, T., Demirgüç-Kunt, A., \& Merrouche, O. (2013). Islamic Vs. Conventional Banking: Business Model, Efficiency and Stability. Journal of Banking and Finance, 37(2), 433-447. https://doi.org/10.1016/j.jbankfin.2012.09.016.

Boulila Taktak, N., Ben Slama Zouari, S., \& Boudriga, A. K. (2010). Do Islamic banks use loan loss provisions to smooth their results? Journal of Islamic Accounting and Business Research, 1(2), 114-127. https://doi.org/10.1108/17590811011086714.

Bouvatier, V., Lepetit, L., \& Strobel, F. (2014). Bank Income Smoothing, Ownership Concentration and The Regulatory Environment. Journal of Banking and Finance, 41(1), 253-270. https://doi.org/10.1016/j.jbankfin.2013.12.001.

Caporale, G. M., Alessi, M., Di Colli, S., \& Lopez, J. S. (2018). Loan Loss Provisions and Macroeconomic Shocks: Some Empirical Evidence for Italian Banks During The Crisis. Finance Research Letters, 25(October), $239-243$. https://doi.org/10.1016/j.frl.2017.10.031.

Ceccobelli, G., \& Giosi, A. (2019). Earnings Management Practices In The Banking Industry: The Role Of Bank Regulation And Supervision. 193-214. https://doi.org/10.22495/cpr19p10.

Cevik, S., \& Charap, J. (2015). The Behavior of Conventional and Islamic Bank Deposit Returns in Malaysia and Turkey. International Journal of Economics and Financial Issues, 5(1), 111-124. https://doi.org/10.5089/9781455293704.001.

Chan, K., Li, F., \& Lin, T. C. (2019). Earnings Management and Post-Split Drift. Journal of Banking and Finance, 101, 136146. https://doi.org/10.1016/j.jbankfin.2019.02.004.

Curcio, D., \& Hasan, I. (2015). Earnings and Capital Management and Signaling: The Use of Loan-Loss Provisions by European Banks. European Journal of Finance, 21(1), 26-50. https://doi.org/10.1080/1351847X.2012.762408.

Dou, Y., Ryan, S. G., \& Zou, Y. (2018). The Effect of Credit Competition on Banks' Loan-Loss Provisions. Journal of Financial and Quantitative Analysis, 53(3), 1195- 1226. https://doi.org/10.1017/S0022109018000054.

Dyreng, S. D., Mayew, W. J., \& Williams, C. D. (2012). Religious Social Norms and Corporate Financial Reporting. Journal of Business Finance and Accounting, 39(7-8), 845-875. https://doi.org/10.1111/j.1468-5957.2012.02295.x.

Elnahass, M., Izzeldin, M., \& Abdelsalam, O. (2014). Loan Loss Provisions, Bank Valuations and Discretion: A Comparative Study Between Conventional and Islamic Banks. Journal of Economic Behavior and Organization, 103. https://doi.org/10.1016/j.jebo.2013.08.018.

Elnahass, M., Izzeldin, M., \& Steele, G. (2016). The Expected Loan Loss Model and Earnings Management : Evidence from Contemporary Practices. Working Paper, 1-28.

Elnahass, M., Izzeldin, M., \& Steele, G. (2018). Capital and Earnings Management: Evidence from Alternative Banking Business Models. International Journal of Accounting, 53(1), 20-32. https://doi.org/10.1016/j.intacc.2018.02.002.

Faradila, A., \& Cahyati, A. (2013). Analisis Manajemen Laba Pada Perbankan Syariah.

None, 4(01), 57-74. https://doi.org/10.33558/jrak.v4i1.272.

Farook, S., Hassan, M. K., \& Clinch, G. (2014). Islamic bank incentives and discretionary loan loss provisions. Pacific Basin Finance Journal, 28, 152-174. https://doi.org/10.1016/j.pacfin.2013.12.006

Funds, T. (2020). The Influence Of Third-Party Funds, Non-Performing Loans ( Npl ) On Credit Distribution With Profitability As. 2020(2), 40-50.

Garsva, G., Skuodas, S., \& Rudzioniene, K. (2012). Earnings Management in European Banks: The Financial Crisis and Increased Incentives For Manipulation Through Loan Loss Provisions. Transformations in Business and Economics, 11(2 A), 504-526.

HT, H. A., \& Rama, A. (2018). Indeks Kinerja Perbankan Syariah di Asia Tenggara Berdasarkan Konsep Maqâshid al-Syarîah. Madania: Jurnal Kajian Keislaman, 22(1), 33. https://doi.org/10.29300/madania.v22i1.782.

Jin, J. Y. (2013). Investor Attention and Earnings Management Around The World. Accounting Perspectives, $12(2), 165-187$. https://doi.org/10.1111/1911-3838.12013.

Kartikasari, D., \& Merianti, M. (2016). The Effect of Leverage and Firm Size to Profitability of Public Manufacturing Companies in Indonesia. International Journal of Economics and Financial Issues, 6(2), 409-413.

Lassoued, N., Attia, M. B. R., \& Sassi, H. (2018). Earnings Management in Islamic and Conventional Banks: Does Ownership Structure Matter? Evidence from the MENA Region. Journal of International Accounting, Auditing and Taxation, 30(December 2017), 85-105. https://doi.org/10.1016/j.intaccaudtax.2017.12.003.

Lobo, G. J. (2017). Accounting Research in Banking - A review. China Journal of Accounting Research, $10(1)$, $1-7$. https://doi.org/10.1016/j.cjar.2016.09.003.

Mamipour, S., \& Sepahi, M. (2015). Analysis of the Behavior of Amateur and Professional Investors' Impact on the Formation of Bubbles in Tehran Stock Market. Iranian Economic Review, 19(3), 341-358. https://doi.org/10.22059/ier.2015.56855. 
Mili, M., Sahut, J. M., Trimeche, H., \& Teulon, F. (2017). Determinants of the Capital Adequacy Ratio of Foreign Banks' Subsidiaries: The Role of Interbank Market and Regulation. Research in International Business and Finance, 42, $442-453$. https://doi.org/10.1016/j.ribaf.2016.02.002.

Mohd Isa, M. Y., Voon Choong, Y., Yong Gun Fie, D., \& Abdul Rashid, M. Z. H. (2018). Determinants of Loan Loss Provisions of Commercial Banks in Malaysia. Journal of Financial Reporting and Accounting, 16(1), 24-48. https://doi.org/10.1108/JFRA-03- 2015-0044.

Mollah, S., \& Zaman, M. (2015). Shari'ah Supervision, Corporate Governance and Performance: Conventional Vs. Islamic Banks. Journal of Banking and Finance, 58, 418- 435. https://doi.org/10.1016/j.jbankfin.2015.04.030.

Mozayani, A. H., \& Parvizi, S. (2016). Exchange Rate Misalignment in Oil Exporting Countries (OPEC): Focusing on Iran. Iranian Economic Review, 20(2), 261-276. https://doi.org/10.22059/ier.2016.58802.

Othman, H. Ben, \& Mersni, H. (2014). The Use of Discretionary Loan Loss Provisions by Islamic Banks and Conventional Banks in the Middle East Region: A Comparative Study. Studies in Economics and Finance, 31(1), 106-128. https://doi.org/10.1108/SEF- 02-2013-0017.

Packer, F., \& Zhu, H. (2012). Loan Loss Provisioning Practices of Asian Banks. SSRN Electronic Journal, 375. https://doi.org/10.2139/ssrn.2038215.

Pinto, I., \& Ng Picoto, W. (2018). Earnings and Capital Management in European Banks Combining a Multivariate Regression With a Qualitative Comparative Analysis. Journal of Business Research, 89(June), $258-264$. https://doi.org/10.1016/j.jbusres.2017.12.034.

Prima Sakti, M. R., \& Mohamad, A. (2018). Efficiency, Stability and Asset Quality of Islamic Vis-À-Vis Conventional Banks: Evidence from Indonesia. Journal of Islamic Accounting and Business Research, 9(3), 378-400. https://doi.org/10.1108/JIABR-07- 2015-0031.

Quttainah, M. A., Song, L., \& Wu, Q. (2013). Do islamic banks employ less earnings management? Journal of International Financial Management and Accounting, 24(3), 203-233. https://doi.org/10.1111/jifm.12011.

Rafay, A., Farid, S., Yasser, F., \& Safdar, S. (2020). Social Collateral and Repayment Performance: Evidence from Islamic Micro Finance. Iranian Economic Review, 24(1), 41-74. https://doi.org/10.22059/ier.2020.74474.

Savitri, E., Andreas, A., Syahza, A., Gumanti, T. A., \& Abdullah, N. H. N. (2020). Corporate governance mechanism and financial performance: Role of earnings management. Entrepreneurship and Sustainability Issues, 7(4), 3395-3409. https://doi.org/10.9770/jesi.2020.7.4(54)

Soedarmono, W., Pramono, S. E., \& Tarazi, A. (2017). The Procyclicality of Loan Loss Provisions in Islamic Banks. Research in International Business and Finance, 39, 911-919. https://doi.org/10.1016/j.ribaf.2016.05.003.

Shawtari, F. A., Ariff, M., \& Abdul Razak, S. H. (2019). Efficiency and Bank Margins: a Comparative Analysis of Islamic and Conventional Banks in Yemen. Journal of Islamic Accounting and Business Research, 10(1), 50-72. https://doi.org/10.1108/JIABR-07- 2015-0033.

Swamy, V. (2017). Determinants of Bank Asset Quality and Profitability: An Empirical Assessment. Applied Economics Quarterly, 63(1), 97-135. https://doi.org/10.3790/aeq.63.1.97.

Wijayanti, R., Diyanty, V., \& Laela, S. F. (2020). Education Strategy Misfit, Board Effectiveness and Indonesian Islamic Bank Performance. Journal of Islamic Accounting and Business Research, 11(3), 929-944. https://doi.org/10.1108/JIABR-042017-0052.

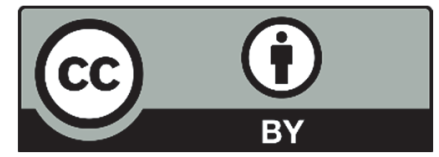

(C) 2021 by the authors; licensee Growing Science, Canada. This is an open access article distributed under the terms and conditions of the Creative Commons Attribution (CC-BY) license (http://creativecommons.org/licenses/by/4.0/). 